\title{
Efektivitas Undang-Undang Nomor 26 Tahun 2000 Tentang Pengadilan Hak Asasi Manusia Dalam Penuntasan Pelanggaran Hak Asasi Manusia (HAM) di Indonesia (Studi Pengadilan HAM Makassar)
}

\author{
A.Yulia Yunara \\ Institut Agama Islam Negeri (IAIN) Bone \\ yuliayunara@gmail.com
}

\begin{abstract}
Abstrak
Tujuan penelitian ini adalah untuk mengetahui efektivitas penerapan UndangUndang Nomor 26 Tahun 2000 tentang Pengadilan Hak Asasi Manusia dalam penuntasan pelanggaran hak asasi manusia di Indonesia dan faktor yang menjadi kendala dalam penerapan Undang-Undang Nomor 26 Tahun 2000 tentang Pengadilan Hak Asasi Manusia dalam penegakan kasus hak asasi manusia di Indonesia. Jenis Penelitian yang digunakan adalah penelitian lapangan dengan menggunakan metode kualitatif. Adapun teknik pengumpulan data yang digunakan adalah wawancara dan dokumentasi. Hasil penelitian menunjukkan bahwa (1) Pelaksanaan Undang-Undang Nomor 26 Tahun 2000 tentang Pengadilan Hak Asasi Manusia (UU Pengadilan HAM) dalam penyelesaian pelanggaran hak asasi manusia di Indonesia khususnya di Pengadilan HAM Makassar belum bisa dikatakan efektif. Hukum acaranya pada tahap penyelidikan, tahap penyidikan, penuntutan dan persidangan dalam kasus pelanggaran HAM sebagian besar aturannya masih menginduk pada KUHAP.
\end{abstract}

\section{Kata Kunci : Efektivitas Undang-Undang Nomor 26 Tahun 2000 dan Pengadilan Hak Asasi Manusia}

\section{PENDAHULUAN}

Hak-Hak Asasi Manusia dalam Islam dibagi menjadi dua bagian besar: Pertama, hak-hak dasar (dharuri), yaitu hak-hak yang jika dilanggar, eksistensi atau harkat kemanusiaan manusia menjadi hilang. Misalnya hak hidup.Kedua, hak-hak sekunder, yaitu hak-hak yang tidak terpenuhi akan berakibat pada hilangnya hak-hak dasar. Pembagian ini sebanding dengan pembagian dalam literatur HAM modern, yaitu hak-hak absolut yang tidak boleh dikurangi. Misalnya hak hidup; hak bebas dari penyiksaan; hak bebas dari perbudakan; hak bebas dari pemidanaan yang berlaku 
surut; dan hak sebagai subjek hukum; dan hak atas kebebasan berpikir, berkeyakinan, dan beragama. Pelanggaran terhadap hak-hak ini tergolong sebagai pelanggaran serius HAM. ${ }^{1}$

Indonesia menganut sistem konstitusional sehingga masalah HAM menjadi hal yang sangat penting, sebab esensi konstitusionalisme itu sendiri pada dasarnya ada dua yakni, perlindungan terhadap HAM dan adanya pembagian kekuasaan negara dengan sistem checks and balances agar pemerintahan dapat memberi perlindungan terhadap HAM. ${ }^{2}$ Dalam sejarah perkembangan Undang-Undang Dasar (UUD) 1945 setelah perubahan kedua pada tahun 2000 dimulai dari Pasal 28A sampai dengan Pasal 28J. ${ }^{3}$ Berakhirnya kekuasaan pemerintahan orde baru yang sangat represif setelah berkuasa selama 32 tahun telah menimbulkan kesadaran akan pentingnya penghormatan HAM. ${ }^{4}$ Pada awal reformasi, salah satu upaya pemerintah untuk menegakkan dan melindungi HAMdengan diundangkannya Undang-Undang Nomor 39 tentang Hak Asasi Manusia pada tanggal 23 September 1999 dan Undang-Undang Nomor 26 Tahun 2000 tentang Pengadilan HAM pada tanggal 23 November $2000 .^{5}$

Penyelesaian perkara pelanggaran HAM merupakan wujud kemajuan, perlindungan dan penegakan HAM sebagaimana telah disepakati oleh negara-negara dalam perjanjian-perjanjian internasional.Negara berkewajiban untuk mengadili para pelaku pelanggaran HAM sesuai dengan peraturan perundang-undangan nasional yang berlaku.Penyelesaian perkara pelanggaran HAM dilaksanakan secara imparsial dan bebas intervensi kepentingan dari pihak manapun, karena para pelaku yang

${ }^{1}$ Sukron Kamil, Pemikiran Politik Islam Tematik: Agama dan Negara, Demokrasi, Civil Society, Syariah dan HAM, Fundamentalisme, dan Antikorupsi, h. 177.

${ }^{2}$ Titik Triwulan Tutik, Konstruksi Hukum Tata Negara Indonesia Pasca Amandemen UUD 1945 (Ed. I, Cet. II; Jakarta: Kencana Prenada Media Group, 2011). h. 292.

${ }^{3}$ Jimly Asshiddiqie, Pengantar Ilmu Hukum Tata Negara (Cet. III; Jakarta: PT Raja Grafindo Persada, 2011), h. 361.

${ }^{4}$ Satrio Saptohadi, "Eksistensi Pengadilan Hak Asasi Manusia Dalam Penegakan Hukum Di Timor Timur Pasca Jajak Pendapat”, Jurnal Dinamika Hukum, Vol. 13, No. 2, Mei 2013. h. 345.

${ }^{5}$ Arief Rianto Kurniawan, "Kedudukan Dewan Perwakilan Rakyat (DPR) Dalam Penyelesaian Pelanggaran Hak Asasi Manusia Yang Berat, Jurnal HAM, Vol. 4, No. 2, Desember 2013. h. 26. 
diadili dapat saja dari pihak militer, polisi dan sipil. ${ }^{6}$ Dalam praktek Pengadilan HAM Indonesia, baik yang bersifat Ad Hoc maupun permanen yang telah dibentuk yang telah menangani perkara pelanggaran berat HAM untuk kasus TimorTimur, Tanjung Priok, dan Abepurapada akhirnya tidak memuaskan rasa keadilan karena pelaku bebas. ${ }^{7}$

Dewasa ini, kita bisa melihat begitu banyak pelanggaran-pelanggaran HAM yang terjadi. Berbagai peristiwapelanggaran HAM di tanah air tidak satupun secara hukum terselesaikan, persoalan penyelesaian pelanggaran HAM di Indonesia selalu menjadi polemik di setiap pergantian pemerintahan.Salah satu kasus yang tidak terselesaikan dengan tuntas dalam Pengadilan HAM adalah kasus peristiwa penembakan mahasiswa Trisakti yang lebih dikenal dengan Tragedi Semanggi I dan II. ${ }^{8}$ Selain itu, ada pula kasus pelanggaran HAM yaitu April Makassar Berdarah (Amarah) peristiwa yang terjadi April 1996 ini menelan korban jiwa 3 mahasiswaUniversitas Muslim Indonesia(UMI) dan ratusan mahasiswa lainnya terluka akibat kampus UMI diserang oknum tentara dan polisi di Kota Makassar. ${ }^{9}$ Pelanggaran HAM pada kasus tersebut belum selesai.Siapa yang harus bertanggungjawab dalam peristiwa tersebut sampai hari ini belum atau tidak bisa ditunjuk tangan apalagi diputus pengadilan padahal nyawa sudah melayang siasia.Apa artinya semua pembunuhan dan perampasan hak-hak sipil yang terjadi selama puluhan tahun. Pengusutan tuntas dengan membawa ke pengadilan untuk menemukan pelaku utamanya sering kali kandas. ${ }^{10}$

\footnotetext{
${ }^{6}$ Jootje Jafet Rafes, "Penyelesaian Perkara Pelanggaran Hak Asasi Manusia (HAM) Berat Prajurit Tentara Nasional Indonesia (TNI)", Vol. 1, No. 3, Juli-September 2013, h. 44.

${ }^{7}$ Yustina Trihoni Nalesti Dewi, "Penguatan Perlindungan Saksi Dan Korban Pada Pengadilan Hak Asasi Manusia”, Jurnal Penelitian Politik, Vol. 14, No. 2, Desember 2017. h. 206-207.

${ }^{8}$ H. Samsul Wahidin, Pokok-Pokok Kewarganegaraan, h. 221.

${ }^{9}$ Muhammad Yunus, "Pelanggaran HAM dituntaskan” dalam https://makassar.terkini.id/aksikamisan-makassar-desak-10-pelanggaran-ham-dituntaskan, 27 Agustus 2019.

${ }^{10}$ Todung Mulya Lubis, Jalan Panjang Hak Asasi Manusia, (Jakarta: PT Gramedia Pustaka Utama, 2005), h. 25.
} 
Sebagai negara hukum, Indonesia belum secara maksimal menghasilkan putusan hukum yang signifikan mencerminkan rasa keadilan sebagai bentuk upaya penegakan hukum bagi para pelaku pelanggaran HAM di Indonesia sebab putusanputusan pengadilan ternyata membebaskan pelaku. Undang-Undang Nomor 26 Tahun 2000 tentang Pengadilan Hak Asasi Manusia mempunyai mandat untuk menyelesaikan pelanggaran HAM di Indonesia dengan kewenangannya untuk mengadili pelanggaran HAM berat di Indonesia, tetapi pada tatanan das sein tidak ada satupun pelanggaran HAM berat yang dijatuhkan sanksi oleh pengadilan HAM yang secara hukum berarti tidak pernah terjadi pelanggaran HAM, sedangkan pada tatanan das sollen diatur apa saja yang merupakan pelanggaran HAM yang dituangkan dalam Undang-Undang Nomor 26 tahun 2000 tentang Pengadilan Hak Asasi Manusia. Berdasarkan uraian diatas, maka penulis merasa tertarik untuk mengkaji mengenai penyelesaian pelanggaran hak asasi manusia berdasarkan peraturan perundang-undangan yang berlaku dan menuangkannya dalam judul penelitian ini dengan judul "Efektivitas Undang-Undang Nomor 26 Tahun 2000 Tentang Pengadilan Hak Asasi Manusia Dalam Penuntasan Pelanggaran Hak Asasi Manusia (HAM) Di Indonesia (Studi Pengadilan HAM Makassar)”.

Berdasarkan dari latar belakang yang dipaparkan diatas, maka dapat peneliti merumuskan masalah sebagai berikut, Bagaimana efektivitas penerapan Undang-Undang Nomor 26 Tahun 2000 tentang Pengadilan Hak Asasi Manusia dalam penuntasan pelanggaran hak asasi manusia di Indonesia dan Apakah faktor yang menjadi kendala dalam penerapan Undang-Undang Nomor 26 Tahun 2000 tentang Pengadilan Hak Asasi Manusia dalam penegakan kasus hak asasi manusia di Indonesia. 


\section{TINJAUAN PUSTAKA}

Untuk melihat kedudukan penelitian ini, di antara penelitian dan tulisan yang relevan, maka upaya penelusuran berbagai sumber yang memiliki relevansi dengan pokok permasalahan dalam penelitian ini telah peneliti lakukan. Tujuan pengkajian pustaka ini, antara lain agar fokus penelitian tidak merupakan pengulangan dari penelitian dan tulisan sebelumnya, melainkan untuk mencari sisi lain yang signifikan untuk diteliti dan dikembangkan. Dalam menyusunan Penelitian ini, peneliti menggunakan beberapa hasil penelitian yang dianggap relevan dengan pembahasan tentang "Efektivitas Undang-Undang Nomor 26 Tahun 2000 Tentang Pengadilan Hak Asasi Manusia Dalam Penuntasan Pelanggaran Hak Asasi Manusia (HAM) di Indonesia (Studi Pengadilan HAM Makassar)". Beberapa referensi yang dimaksud sebagai berikut :

Penelitian yang disusun oleh Alvira Metha Varicia, Mahasiswa Fakultas Hukum, Universitas Lampung, Bandar Lampung 2015 yang berjudul “Analisis Faktor Penghambat Penyidikan dan Penuntutan Pelanggaran Berat Hak Asasi Manusia”. Dalam Penelitian tersebut lebih fokus terhadap faktor penghambat dalam penyidikan dan penuntutan pelanggaran hak asasi manusia berat dan upaya mengatasi faktorfaktor penghambat penyidikan dan penuntutan pelanggaran hak asasi manusia berat. Dari hasil penelitian tersebut ditarik kesimpulan bahwa,faktor penghambat penanganan HAM berat adalah lokasi pelanggaran HAM yang berat umumnya terletak jauh dari ibu kota, sementara jaksa yang memahami masalah pelanggaran HAM yang berat umumnya berada di Jakarta, sehingga untuk melakukan pemeriksaan (penyidikan) perkara-perkara pelanggaran HAM yang berat akan terbentur dengan masalah SDM dan pembatasan yang diatur dalam undang-undang. 
Kendala pembatasan ini juga berhubungan dengan ketersediaan anggaran dan kesiapan pengadilan HAM Ad Hoc dalam penanganannya. ${ }^{11}$

Penelitian yang disusun oleh Imam Setiawan Mahasiswa Bagian Hukum Acara, Fakultas Hukum, Universitas Hasanuddin 2013 yang berjudul "Tinjauan Terhadap Hukum Acara Peradilan Dalam Praktek Peradilan HAM’. Dalam Penelitian tersebut lebih fokus terhadapsejauhmana ketentuan hukum yang spesifik, yang diterapkan dalam melakukan proses penyelidikan dan penyidikan dalam suatu kasus HAM dan kecenderungan hakim dalam memutus hukum dalam kasus pelanggaran HAM. Dari hasil penelitian tersebut ditarik kesimpulan bahwa, ketentuan hukum yang spesifik yang diterapkan dalam melakukan proses penyelidikan dan penyidikan dalam suatu kasus HAM mengacu pada Undang-Undang Nomor 26 Tahun 2000 tentang Pengadilan HAM dan kecenderungan Hakim dalam memutus kasus HAM adalah "tidak bersalah" ini mengacu pada putusan kasus pelanggaran HAM berat Abepura di Pengadilan Negeri Makassar. ${ }^{12}$ Dari beberapa karya ilmiah atau hasil penelitian yang telah dikemukakan di atas jelas terdapat relevansi dengan penelitian yang dilakukan oleh peneliti.Namun berbagai tulisan tersebut memiliki ciri khas dan fokus masing-masing yang berbeda dengan penelitian ini. Dalam Penelitian ini, peneliti secara signifikan lebih memfokuskan pada efektivitas penerapan UndangUndang Nomor 26 Tahun 2000 tentang Pengadilan Hak Asasi Manusia dalam penegakan kasus HAM di Indonesia dan faktor yang menjadi kendala dalam penerapan Undang-Undang Nomor 26 Tahun 2000 tentang Pengadilan Hak Asasi Manusia dalam penegakan kasus HAM di Indonesia.

\footnotetext{
${ }^{11}$ Alvira Metha Viricia, "Analisis Faktor Penghambat Penyidikan dan Penuntutan Pelanggaran Hak Asasi Manusia Berat", (Skripsi, Fakultas Hukum, Universitas Lampung, Bandar Lampung, 2010). h. 85

${ }^{12}$ Imam Setiawan, "Tinjauan Terhadap Hukum Acara Peradilan Dalam Praktek Peradilan HAM" (Skripsi, Bagian Hukum Acara, Fakultas Hukum, Universitas Hasanuddin, Makassar, 2013). h. 57
} 


\section{METODE PENELITIAN}

\section{Jenis dan Pendekatan Penelitian}

a. Jenis Penelitian

Berdasarkan permasalahan yang telah dikemukakan diatas makajenis penelitian ini, penelitian kualitatif.Penelitian kualitatif adalah penelitian yang langsung berhubungan dengan objek yang diteliti untuk memperoleh keterangan yang dibutuhkan.Peneliti kualitatif terlibat langsung dalam interaksi dengan realitas yang ditelitinya. ${ }^{13}$ Dalam hal ini peneliti langsung melakukan penelitian di Pengadilan HAM Makassar untuk memperoleh informasi dari responden terkait adanya pelanggaran HAMyang terjadi.

b. Pendekatan Penelitian

Penelitian yang dilakukan oleh penulis menggunakan pendekatan normatif empiris.Pendekatan normatif empiris adalah pendekatan dengan mengacu kepada norma-norma hukum yang berlaku di masyarakat. ${ }^{14}$

\section{Lokasi Penelitian}

Penelitian dilaksanakan di Kota Makassar yakni di Pengadilan HAM (dalam hal ini Pengadilan Negeri Kelas 1A Khusus Makassar),yang beralamat di Jln. R.A Kartini No.18/23, Baru, Ujung Pandang, Kota Makassar, Sulawesi Selatan. Pemilihan lokasi penelitian didasarkan atas pertimbangan bahwa Pengadilan HAM Makassar dapat diperoleh data-data terkait dengan objek permasalahan yang akan diteliti oleh penulis.

\footnotetext{
${ }^{13}$ Gumilar Rusliwa Somantri, “Memahami Metode Kualitatif”, Sosial Humaniora, Vol. 9, No. 2, Desember 2005, h. 58.

${ }^{14}$ Zainuddin Ali, Metode Penelitian Hukum (Cet. V; Jakarta: Sinar Grafika, 2014), h. 105 
8 | A.Yulia Yunara

\section{Data dan SumberData}

a. Dataadalah segala keterangan (informasi) mengenai segala hal yang berkaitan dengan tujuan penelitian. ${ }^{15}$

b. Sumber data

Sumber data yang digunakan peneliti dalam penelitian ini adalah:

1) Data primer adalah data yang menjadi bahan dasar dalam melakukan penelitian lapangan yang diperoleh dari jawaban-jawaban yang diberikan oleh narasumber atau data yang diperoleh langsung dari lapangan. ${ }^{16}$ Adapun data primer penelitian dari Pengadilan HAM Makassar.

2) Data sekunder adalah data yang diperoleh dari dokumen-dokumen resmi, buku-buku yang berhubungan dengan objek penelitian, hasil penelitian dalam bentuk laporan, Penelitian, tesis, disertasi, dan peraturan perudang-undangan, ${ }^{17}$ jurnal-jurnal hukum. ${ }^{18}$ Adapun data sekunder penelitian ini adalah UUD NRI 1945, Undang-Undang Nomor 39 Tahun 1999 tentang Hak Asasi Manusia, dan Undang-Undang Nomor 26 Tahun 2000 Tentang Pengadilan Hak Asasi Manusia, hasilhasil penelitian, pendapat para pakar hukum, jurnal-jurnal hukum, dan Penelitian.

3) Data Tersier adalah data yang memberikan petunjuk maupun penjelasan terhadap data primer dan sekunder yang terdiri dari artikel, internet,

\footnotetext{
${ }^{15}$ Tatang M. Amirin, Menyusun Rencana Penelitian (Cet. III; Jakarta: PT Raja Grafindo Persada, 1995), h. 130.

${ }^{16}$ Amiruddin dan H. Zainal Asikin, Pengantar Metode Penelitian Hukum (Jakarta: PT. Raja Grafindo Persada, 2006), h. 30.

${ }^{17}$ Zainuddin Ali, Metode Penelitian Hukum, h. 106.

${ }^{18}$ Peter Mahmud Marzuki, Penelitian Hukum (Cet.VII; Jakarta: Prenamedia Group, 2011), h. 181 .
} 
kamus hukum dan Insiklopedia. ${ }^{19}$

\section{Intrumen Penelitian}

a. Penelitian lapangan merupakan penelitian dimana peneliti terjun langsung pada tempat di mana peneliti melakukan penelitian untuk mengumpulkan data. Dalam penelitian ini instrumen yang digunakan oleh peneliti adalah daftar pertanyaan dan alat tulis.

b. Penelitian kepustakaan yaitu penelitian mengumpulkan data melalui studi dokumen dengan cara membaca dokumen yang memiliki hubungan dengan penelitian penulis, baik berupa teori maupun bahan lainnya yang dapat menunjang dalam pembahasan Penelitian penulis.

5. Teknik Pengumpulan Data

Dalam penelitian ini penulis menggunakan teknik wawancara dan dokumentasi dalam mengumpulkan data yaitu:

a. Wawancara, yakni teknik pengumpulan data dengan cara mengajukan pertanyaansecara langsung oleh peneliti kepada HakimPengadilan HAMMakassar tersebut yang selanjutnya akan dianalisis peneliti.

b. Dokumentasi merupakan suatu cara pengumpulan data yang dilakukan dengan menganalisis isi dokumen yang berhubungan dengan masalah yang diteliti. Metode ini digunakan untuk mengumpulkan data yang sudah tersedia dalam catatan dokumen, seperti konsep teori yang berkaitan dengan variabel yang diteliti. ${ }^{20}$

\section{Teknik AnalisisData}

Setelah data dikumpulkan baik data primer, data sekunder dan data tersier. Dalam penulisan Penelitian ini penulis menggunakan analisis h. 13 .

${ }^{19}$ Soerjono Soekanto, Penelitian Hukum Normatif (Cet. XIII; Jakarta: Rajawali Press, 2011),

${ }^{20}$ S. Eko Putro Widoyoko, Teknik Penyusunan Instrumen (Cet. I; Yogyakarta: Pustaka Pelajar, 2012), h. 49. 
10 | A.Yulia Yunara

deskriptif kualitatif yaitu dengan mendePenelitiankan data yang dihasilkan dalam bentuk penjelasan atau uraian kalimat yang disusun secara sistematis dari analisis data tersebut dilanjutkan dengan menarik kesimpulan secara deduktifsuatu cara berfikir yang didasarkan fakta-fakta yang bersifat umum kemudian ditarik suatu kesimpulan secara khusus yang merupakan jawaban permasalahan berdasarkan hasil penelitian.

\section{HASIL PENELITIAN DAN PEMBAHASAN}

Faktor yang menjadi kendala dalam penerapan Undang-Undang Nomor 26 Tahun 2000 Tentang Pengadilan Hak Asasi Manusia dalam penegakan kasus hak asasi manusia di Indonesia

Faktor-faktor yang dijadikan indikator oleh penulis untuk mengetahui hambatan dalam penerapan Undang-Undang Nomor 26 Tahun 2000 Tentang Pengadilan Hak Asasi Manusia.penulis akan menghubungkan dengan teori dari Soerjono Soekanto tentang faktor yang mempengaruhi penegakan atau keefektifan hukum, yaitu:Faktor hukumnya sendiri (undang-undang), faktor penegak hukum, faktor masyarakat, faktor sarana atau fasilitas dan faktor budaya hukum. ${ }^{21}$

Selanjutnya Penulis akan memaparkan hasil penelitian yaitu sebagai berikut :

1. Faktor hukum

Sebagai sumber hukum, perundang-undangan mempunyai kelebihan karena ia dikaitkan pada kekuasaan yang tertinggi di suatu negara dan karenanya pula memiliki kekuasaan memaksa yang besar sekali. Dalam praktik penyelenggaraan hukum dilapangan ada kalanya terjadi pertentangan antara

\footnotetext{
${ }^{21}$ Soejono Soekanto, Faktor-Faktor yang Mempengaruhi Penegakan Hukum (Jakarta: PT. Raja Grafindo Persada, 2008), h. 8.
} 
kepastian hukum dan keadilan. Hal ini disebabkan oleh konsepsi keadilan merupakan suatu rumusan yang bersifat abstrak, sedangkan kepastian hukum merupakan suatu prosedur yang telah ditentukan secara normatif. Suatu kebijakan atau tindakan yang tidak sepenuhnya berdasar merupakan suatu yang dapat dibenarkan sepanjang kebijakan atau tindakan itu tidak bertentangan dengan hukum. ${ }^{22}$

Berdasarkan pengumpulan data yang dilakukan peneliti dengan memberikan pertanyaan kepada hakim melalui wawancara. Penulis menanyakan pendapat Hakim tentang Undang-Undang Nomor 26 Tahun 2000 Tentang Pengadilan Hak Asasi Manusia, apakah sudah sesuai ataukah masih banyak kekurangan.

"Untuk saat ini, Undang-Undang Nomor 26 Tahun 2000 Tentang Pengadilan Hak Asasi Manusia sudah sesuai dengan kondisi hukum di Indonesia. Adapun Undang-Undang Nomor 26 Tahun 2000 Tentang Pengadilan Hak Asasi Manusia ini merupakan undang-undang terjemahan dari statuta roma". ${ }^{23}$

Berdasarkan hasil wawancara, maka didapatkan hasil bahwa kualitas peraturan perundang-undangan, berkaitan dengan materi muatan undang-undang telah tersusun secara lengkap dan memadai, serta terstruktur dan mudah dipahami. Undang-Undang Nomor 26 Tahun 2000 Tentang Pengadilan Hak Asasi Manusiamerupakan undang-undang terjemahan dari statuta roma sehingga dapat menimbulkan tafsir yang berbeda-beda oleh Hakim. Agar lebih sesuai

\footnotetext{
${ }^{22}$ Ria Ayu Novita, Agung Basuki Prasetyo dan Suparno, "Efektivitas Pelaksanaan UndangUndang Nomor 2 Tahun 2960 Tentang Perjanjian Bagi Hasil Tanah Pertanian (Tanah Kering) Di Desa Bringin, Kecamatan Bayan, Kabupaten Purworejo", Jurnal Dipenogoro Law Jurnal, Vol. 6, No.2, 2017, h. 4

${ }^{23}$ Bambang Nurcahyono, Hakim Pengadilan Negeri Kelas 1A Khusus Makassar, wawancara oleh penulis di Ruang Hakim 1 Pengadilan Negeri Kelas 1A Khusus Makassar, 8 Agustus 2019.
} 
dengan perkembangan jaman, maka seringkali undang-undang harus direvisi. Revisi merupakan klarifikasi terhadap kekurangan-kekurangan yang dahulu sering kali digunakan ini sebagai solusi atau problema pengaturan yang tidak jelas atau melahirkan multi tafsir.

2. Faktor penegak hukum

Penegak hukum berfungsi untuk menyempurnakan tujuan hukum, yakni terpenuhinya ketertiban dan rasa keadilan masyarakat.Penegak hukum adalah pemegang hak dan kewajiban dalam pengawasan dan berlaku efektifnya sebuah undang-undang atau hukum itu sendiri. Dapat dikatakan bahwa penegak hukum adalah hukum yang berjalan (aktif), untuk merubah masyarakat tentu penegak hukum seharusnya paham pada aturan dan terlebih dahulu mengimplementasikan hukum dalam dirinya sendiri. ${ }^{24}$

Penegak hukum atau orang yang bertugas menerapkan hukum mempunyai ruang lingkup yang luas karena mencakup mereka yang secara langsung berkecimpung di bidang penegakan hukum.Setiap penegak hukum mempunyai kedudukan dan peranan. Oleh karena itu, seorang penegak hukum yang mempunyai kedudukan tertentu dengan sendirinya memiliki wewenang untuk melakukan sesuatu berdasarkan jabatannya. ${ }^{25}$

Seorang penegak hukum, sebagaimana halnya dengan warga-warga masyarakat lainnya, biasanya mempunyai beberapa kedudukan dan peranan

\footnotetext{
${ }^{24}$ Mohamad Aidil, "Efektifitas Penerapan Undang-Undang Nomor 35 Tahun 2009 Tentang Narkotika di Kota Palu", Jurnal Katalogis, Vol. 3, No. 10, Oktober 2015, h. 22.

${ }^{25}$ Dian Eko Prakoso, "Efektivitas Peraturan Daerah Nomor 17 Tahun 2006 Tentang Pengelolaan Parkir Tepi Jalan Umum Dalam Daerah Kota Makassar (Suatu Tinjauan Sosiologi Hukum)", (Skripsi, Bagian Hukum Masyarakat Dan Pembangunan, Fakultas Hukum, Universitas Hasanuddin, Makassar, 2014), h. 46-47.
} 
sekaligus. Dengan demikian tidaklah mustahil bahwa antara berbagai kedudukan dan peranan timbul konflik. Kalau di dalam kenyataanya terjadi suatu kesenjangan antara peranan yang seharusnya dilakukan dengan peranan yang sebenarnya dilakukan. ${ }^{26}$

Dalam hal ini Pengadilan HAM Makassar mempunyai mandat untuk mengadili pelaku pelanggaran HAM sebagaimana diamanatkan dalam UndangUndang Nomor 26 Tahun 2000 Tentang Pengadilan Hak Asasi Manusia.

Penulis melakukan wawancara pada Bambang Nurcahyono, S.H., M.Hum selaku Hakim terkait para penegak hukum apakah Hakim sudah melaksanakan tugas dan kewajibannya dengan baik.

"Penegak hukum dalam hal ini Hakim telah melaksanakan tugasnya sebagaimana yang diamanatkan dalam Undang-Undang Nomor 26 Tahun 2000 Tentang Pengadilan Hak Asasi Manusia karena hal itu merupakan suatu kewajiban yang harus dilaksanakan". ${ }^{27}$

Berdasarkan wawancara yang telah dilakukan oleh penulis dapat diperoleh bahwa penegak hukum yang dimaksud dalam hal ini adalah Hakim dalam berfungsinya hukum, mentalitas atau kepribadian petugas penegak hukum memainkan peranan penting kalau peraturan sudah baik, tetapi kualitas petugas kurang baik ada masalah maka akan menimbulkan efek pada sistem penegakan hukum. Dalam hal ini penegak hukum dimaksud khususnya mengenai penjatuhan hukuman kepada pelaku pelanggaran HAM agar kiranya diberikan hukuman yang setimpal dari pelanggaran yang dilakukan.

\footnotetext{
${ }^{26}$ Ria Ayu Novita, Agung Basuki Prasetyo dan Suparno, "Efektivitas Pelaksanaan UndangUndang Nomor 2 Tahun 2960 Tentang Perjanjian Bagi Hasil Tanah Pertanian (Tanah Kering) Di Desa Bringin, Kecamatan Bayan, Kabupaten Purworejo", Jurnal Dipenogoro Law Jurnal, Vol. 6, No.2, 2017 , h. 6.

${ }^{27}$ Bambang Nurcahyono, Hakim Pengadilan Negeri Kelas 1A Khusus Makassar, wawancara oleh penulis di Ruang Hakim 1 Pengadilan Negeri Kelas 1A Khusus Makassar, 8 Agustus 2019.
} 
3. Faktor sarana dan fasilitas pendukung

Dalam hal pengadaan tempat penanganan penyelesaian pelanggaran HAM. Sehubungan dengan itu maka penulis mengajukan pertanyaan yang relevan sebab peradilan HAM yang mewakili wilayah Indonesia Timur hanya terdapat di Makassar. Maka diperoleh jawaban sebagai berikut:

"Pengadilan HAM hanya terdapat di wilayah kota Makassar dikarenakan Makassar merupakan ibu kota provinsi Sulawesi Selatan berada di dalam naungan Pengadilan Negeri Kelas 1A Khusus Makassar dikarenakan sarana danfasilitasnya lengkap" 28

Selain itu, peneliti juga menanyakan, terkait kenapa Pengadilan HAM Makassar tidak memiliki hakim dan gedung pengadilan sendiri. Bambang Nurcahyono, S.H ., M.H selaku hakim mengemukakan bahwa:

"Pengadilan HAM Makassar tidak memiliki hakim dan tidak memiliki gedung pengadilan sendiri bersifat permanen dikarenakan anggaran negara yang terbatas. Adapun Hakim di Pengadilan ini belum ada di bidang khususnya HAM adanya hakim di bidang tipikor, pidana, perdata dsb". ${ }^{29}$

Berdasarkan hasil wawancara diatas, Pengadilan HAM khususnya wilayah Indonesia Timur hanya terdapat di Makassar karena anggaran negara yang terbatas dan Hakim di Pengadilan HAM Makassar dalam hal ini Pengadilan Negeri Kelas 1A Khusus Makassar tidak memiliki Hakim khusus di bidang HAM. Jadi, Hakim bersifat Ad hoc yaitu apabila terdaftar pelanggaran yang dikategorikan dalam perkara pelanggaran HAM barulah diadakan penunjukan terhadap Hakim yang memiliki kompetensi/pengetahuan di bidang tersebut. Untuk memperoleh keberhasilan hukum atau efektivitas hukum maka diperlukan sarana atau fasilitas yang mendukung dalam menjalankan aturan tersebut. Tanpa

\footnotetext{
${ }^{28}$ Bambang Nurcahyono, Hakim Pengadilan Negeri Kelas 1A Khusus Makassar, wawancara oleh penulis di Ruang Hakim 1 Pengadilan Negeri Kelas 1A Khusus Makassar, 8 Agustus 2019.

${ }^{29}$ Bambang Nurcahyono, Hakim Pengadilan Negeri Kelas 1A Khusus Makassar, wawancara oleh penulis di Ruang Hakim 1 Pengadilan Negeri Kelas 1A Khusus Makassar, 8 Agustus 2019.
} 
adanya sarana atau fasilitas tersebut tidak akan mungkin penegak hukum menyerasikan peranan yang seharusnya dengan peranan yang aktual.

\section{Faktor Masyarakat}

Salah satu faktor yang mengefektifkan suatu peraturan adalah warga masyarakat. Yang dimaksud di sini adalah kesadarannya untuk mematuhi suatu peraturan perundang-undangan yang kerap disebut derajat kepatuhan. Bila suatu peraturan perundang-undangan telah diundangkan dan diterbitkan menurut prosedur yang sah dan resmi, maka secara yuridis peraturan perundang-undangan itu berlaku. Kemudian timbul asumsi bahwa setiap warga masyarakat dianggap mengetahui adanya undang-undang tersebut. Namun, asumsi tersebut tidaklah seperti demikian adanya. ${ }^{30}$

Penegakan hukum berasal dari masyarakat dan bertujuan untuk mencapai kedamaian didalam masyarakat. Dengan begitu maka masyarakat dapat mempengaruhi penegakan hukum. Penegakan hukum bukanlah merupakan suatu kegiatan yang berdiri sendiri, melainkan mempunyai hubungan timbal balik yang erat dengan masyarakatnya. Dan diketahui pula untuk mencapai kedamaian harus ada kepatuhan dari masyarakat. Dan kepatuhan tersebut antara lain ditentukan ada kesadaran hukum. Kesadaran hukum merupakan nilai-nilai yang terdapat didalam diri manusia tentang hukum yang ada atau tentang hukum yang

\footnotetext{
${ }^{30}$ Ria Ayu Novita, Agung Basuki Prasetyo dan Suparno, Agung Basuki Prasetyo dan Suparno, "Efektivitas Pelaksanaan Undang-Undang Nomor 2 Tahun 2960 Tentang Perjanjian Bagi Hasil Tanah Pertanian (Tanah Kering) Di Desa Bringin, Kecamatan Bayan, Kabupaten Purworejo", Jurnal Dipenogoro Law Jurnal, Vol. 6, No.2, 2017, h. 6.
} 
diharapkan akan ada. ${ }^{31}$

Pengetahuan masyarakat terhadap Undang-Undang Nomor 26 Tahun 2000 Tentang Pengadilan Hak Asasi Manusia jika telah diketahui adanya, maka dapat dibuat ukuran kepatuhan masyarakat sebagai salah satu faktor penyebab efektif tidaknya undang-undang tersebut.

Mengenai pengetahuan masyarakat tentang HAM, Hakim Pengadilan HAM Makassar mengemukakan bahwa:

"Untuk sebagian masyarakat ada yang sudah mengetahui dan terdapat pula masyarakat dimana pengetahuannya tentang HAM sama sekali tidak mengetahuinya". 32

Berdasarkan hasil wawancara diperolehhasil bahwa pengetahuan masyarakat mengenai HAM dapat dikatakan masih sebagian kecil yang memahami tentang HAM. Pengetahuan yang kurang dari masyarakat akan mengakibatkan kesewenang-wenangan dengan melakukan berbagai pelanggaranpelanggaran yang dapat mengakibatkan hilangnya hakekat keberadaan HAM orang lain akibat perbuatan yang tidak manusiawi.Masyarakat dalam hal ini menjadi faktor yang cukup mempengaruhi juga didalam efektivitas hukum.

5. Faktor Budaya Hukum

Budaya hukum adalah bagaimana sikap masyarakat hukum di tempat hukum itu dijalankan. Berkaitan dengan hal tersebut maka peneliti menanyakan apakah kebiasaan yang ada dalam masyarakat dapat dikatakan menjaga HAM.

"Kebiasaan dalam masyarakat dapat menjaga HAM setiap orang. Adanya budaya "malu" atau budaya perasaan bersalah dari warga masyarakat

\footnotetext{
${ }^{31}$ Elly Rosana, "Kepatuhan Hukum Sebagai Wujud Kesadaran Hukum Masyarakat”, Jurnal TAPIS, Vol. 10, No. 1, Januari-Juni 2014, h. 3.

${ }^{32}$ Bambang Nurcahyono, Hakim Pengadilan Negeri Kelas 1A Khusus Makassar, wawancara oleh penulis di Ruang Hakim 1 Pengadilan Negeri Kelas 1A Khusus Makassar, 8 Agustus 2019.
} 
dalam kehidupan sehari-hari”. ${ }^{33}$

Berdasarkan hasil wawancara, maka didapatkan hasil bahwa kebiasaan dalam kehidupan sehari-hari dapat dikatakan menjaga HAM. Kebiasaan atau budaya dimana nilai, sikap, dan perilaku para warga masyarakat termasuk pejabat pemerintahan terhadap atau berkenaan dengan hukum. Apabila kesadaran masyarakat untuk mematuhi peraturan yang telah ditetapkan dapat diterapkan maka masyarakat akan menjadi faktor pendukung. Namun, bila masyarakat tidak mau mematuhi peraturan yang ada maka masyarakat akan menjadi faktor penghambat utama dalam penegakan.

\section{PENUTUP}

\section{Kesimpulan}

Berdasarkan hasil penelitian dan pokok masalah yang telah dibahas oleh penyusun, maka dapat ditarik kesimpulan sebagaiberikut:

1. Pelaksanaan Undang-Undang Nomor 26 Tahun 2000 Tentang Pengadilan Hak Asasi Manusia dalam penyelesaian pelanggaran hak asasi manusia di Indonesia khususnya di Pengadilan HAM Makassar belum bisa dikatakan efektif.Undang-UndangNomor 26 Tahun 2000 Tentang Pengadilan Hak Asasi Manusia pada hukum acaranya pada tahap penyelidikan, tahap penyidikan, penuntutan dan persidangan dalam kasus elanggaran HAM sebagian besar aturannya masih menginduk pada KUHAP. Padahal di sisi lain, kasus pelanggaran HAM memiliki karakteristik tersendiri. Selain itu, ketidakjelasan unsur rumusan di dalam pengertian kejahatan kemanusiaan, tidak ada mekanisme menyelesaikan perbedaan pendapa tantara Komnas

\footnotetext{
${ }^{33}$ Bambang Nurcahyono, Hakim Pengadilan Negeri Kelas 1A Khusus Makassar, wawancara oleh penulis di Ruang Hakim 1 Pengadilan Negeri Kelas 1A Khusus Makassar, 8 Agustus 2019. 
HAM selaku penyilidik dan Jaksa Agung selaku penyidik.Komnas HAM sesuai dengan keahliannya seringkali menggunakan perspektif HAM bagi sebuah kejahatan luarbiasa/berat sedangkan Kejaksaan Agung melihatnya dari kacamata hukum pidana biasa.

2. Faktor penghambat dari pelaksanaan Undang-UndangNomor 26 Tahun 2000 Tentang Pengadilan Hak Asasi Manusia yaitu: (a) Aturan hukum yang digunakan masih menimbulkan multitafsir dalam penerapannya. (b)Penegak hukum dalam hal ini hakim dalam berfungisnya hukum, kalau peraturan sudah baik, tetapi kualitas petugas kurang baik berarti ada masalah. (c) sarana dan fasilitas pendukung dimana Pengadilan HAM tidak memiliki Hakim dibidang HAM untuk menyelesaikan pelanggaran HAM dilakukan penunjukan Hakim Ad hoc yang dipilihberdasarkan dari kompetensi hakim. (d) Kesadaran masyarakat dalam mematuhi hukum dan pemahamannya masyaraka tentang HAM masih dan (e) budaya hukum seringkali masyarakat tidak mau mematuhi peraturan yang ada sehingga dapaat menghambat dalam penegakan peraturan.

\section{DAFTAR REFERENSI}

\section{A. Buku-Buku}

Ali, Zainuddin. Metode Penelitian Hukum. Cet. V. Jakarta: Sinar Grafika, 2014.

Amirin, Tatang M. Menyusun Rencana Penelitian. Cet. III. Jakarta: PT Raja Grafindo Persada, 1995.

Arake, H. Lukman. Islam danKonseptualisasiPolitikKaumMinoritas.Cet. 1. Yogyakarta: Prudent Media, 2012.

Asikin, H. Zainal dan Amiruddin. Pengantar Metode Penelitian Hukum. Jakarta: PT. Raja Grafindo Persada, 2006. 
Asikin, H. Zainal. Pengantar Ilmu Hukum. Ed. 1. Cet. II. Jakarta: Rajawali Pers, 2013.

Asshiddiqie, Jimly.Pengantar Ilmu Hukum Tata Negara. Cet. III. Jakarta: PT Raja GrafindoPersada, 2011.

------.Pengantar Ilmu Hukum Tata Negara. Ed. I. Cet. III. Jakarta: PT Raja Grafindo Persada, 2011

-------Pengantar Ilmu Hukum Tata Negara. Cet. VI. Jakarta: PT Raja Grafindo Persada, 2014

BJ Habibie.Pandangan dan Langkah ReformasiCet. I. Jakarta: PT Raja Grafindo Persada, 1999.

Budiardjo, Miriam Dasar-dasar Ilmu Politik. Jakarta: PT Gramedia Pustaka Utama, 2008.

Cassese, Antonio. Hak AsasiManusia Di Dunia Yang Berubah, Cet.I. Jakarta :YayasanObor Indonesia, 2005.

Departemen Agama RI. Al-Qur'an danTerjemahnya (AyatPojokBergaris.) Semarang: CV AsySyifa, 1998.

Friska, Sondang dan Eddie Riyadi.Penerjema: Genosida, KejahatanTerhadapKemanusiaaan, Dan Kejahatan Perang. Cet. 1. Jogjakarta: ELSAM, 2007.

H. TJandrasari, dan W Yudho. Efektivitas Hukum dalamMasyarakat. Jakarta: Majalah Hukum dan Pembangunan, UI Press, 1987.

Huda, Ni'Matul. Hukum Tata Negara.Ed. Revisi. Cet. X. Jakarta: PT Raja Grafindo Persada, 2015.

Indra, Mexsasai. DinamikaHukum Tata Negara Indonesia.Cet. I Bandung : PT RefrikaAdimita, 2011.

Jazim Hamidi dkk, Teori Hukum Tata Negara: a Turning Point of The State. Jakarta: Salemba Humanika, 2012.

Kamil, Sukron. PemikiranPolitik Islam Tematik: Agama dan Negara, Demokrasi, Civil Society, Syariahdan HAM, Fundamentalisme, danAntikorupsi. Ed. 1.Cet. 1. Jakarta: Kencana, 2013.

Kusnardi, Moh. Pengantar Hukum Tata Negara Indonesia. Jakarta: CV Sinar Grafika, [tt]

Lubis, TodungMulya. JalanPanjangHakAsasiManusia. Jakarta: PT GramediaPustakaUtama, 2005.

Manan, H. Abdul.PolitikHukum:StudiPerbandinganDalamPraktikKetatanegaraan Islam danSistemHukum Barat. Ed. 1.Cet. 1. Jakarta: Prenamedia Group, 2016.

Marzuki, Peter Mahmud. PenelitianHukum. Cet.VII. Jakarta: Prenamedia Group, 2011.

Nasution, Bahder Johan. Negara Hukum Dan HakAsasiManusia. Cet. II. Bandung: MandarMaju, 2012. 
Qamar,Nurul.Pengantar Hukum Tata Negara. Cet. I. Makassar: Arus Timur, 2015.

R. Wiyono, PengadilanHakAsasiManusia di Indonesia. Ed. II, Cet. III; Jakarta: Prenadamedia Group, 2015.

Riyadi, Eddie danSondangFriska.Penerjema: Genosida, KejahatanTerhadapKemanusiaaan, Dan KejahatanPerang. Cet. 1. Jogjakarta: ELSAM, 2007.

Rocky Marbun, dkk, KamusHukumLengkap.Cet. I. Jakarta Selatan: CiganjurJagakarsa, 2012.

Savitri, Niken .HAM PerempuanKritikTeoriHukumFeminisTerhadap KUHP.Cet. I Bandung: PT RefikaAditama, 2008.

Shiddieqh, T. Muhammad Hasby Ash. Islam danHakAsasiManusia. Semarang: PT. PustakaRizki Putra, 1999.

Sochmawardiah, Hesti Arniwulan.Diskriminasi Rasial Dalam Hukum HAM. Yogyakarta: Genta Publishing, 2013.

Soekanto, Soekanto. Faktor-Faktor yang MempengaruhiPenegakanHukum. Jakarta: PT. Raja GrafindoPersada, 2008.

Sukardja, H. Ahmad.Hukum Tata Negara dan Hukum Administrasi Negara Dalam Perspektif Fikih Siyasah. Cet. II. Jakarta: Sinar Grafika, 2014.

Syamsir, danRozali Abdullah.Perkembangan Ham Dan KeberadaanPengadilan Ham Di Indonesia. Cet. 1, Jakarta :Ghalia Indonesia, 2002.

Tutik, TitikTriwulan. KonstruksiHukum Tata Negara Indonesia PascaAmandemen UUD 1945.Ed. 1. Cet. II. Jakarta: KencanaPrenada Media Group, 2011.

Undang-Undang Hak Asasi Manusia 1999. Cet. XI. Jakarta: Sinar Grafika Offset, 2014.

Wahidin, H. Samsul. Pokok-PokokPendidikanKewarganegaraan.Cet. I. Yogyakarta: PustakaPelajar, 2010.

Widoyoko, S. EkoPutro. TeknikPenyusunanInstrumen. Cet. I; Yogyakarta: PustakaPelajar, 2012.

\section{B. Jurnal, Penelitian.}

Aidil, Mohamad. "Efektifitas Penerapan Undang-UndangNomor 35 Tahun2009 Tentang Narkotika di Kota Palu”. Jurnal Katalogis. Vol. 3. No. 10. Oktober 2015.

Darodi. "Efektivitas Penegakan Hukum Peraturan Daerah Kota Pekalongan Nomor 19 Tahun 2012 Tentang Kawasan Tanpa Rokok (Studi Terhadap Anggota Polri Polres Pekalongan Kota)". Jurnal Idea Hukum.Vol. 2.No. 1.Maret 2016.

Dewi, Yustina Trihoni Nalesti. "Penguatan Perlindungan Saksi Dan KorbanPada Pengadilan Hak Asasi Manusia”. Jurnal Penelitian Politik. Vol. 14.No. 2.Desember 2017. 
Kurniawan, Arief Rianto. "Kedudukan Dewan Perwakilan Rakyat (DPR) Dalam Penyelesaian Pelanggaran Hak Asasi Manusia Yang Berat.Jurnal HAM. Vol. 4.No. 2.Desember 2013.

Kusnadi, Nandang. "Perspektif Penegakan Hak Asasi Manusia Melalui Pengadilan Hak Asasi Manusia”. Jurnal Law. Vol. 3. No. 1. Januari 2017.

Novita, RiaAyuAgungBasukiPrasetyodanSuparno. "EfektivitasPelaksanaanUndangUndangNomor 2 Tahun 2960 TentangPerjanjianBagiHasil Tanah Pertanian (Tanah Kering) Di DesaBringin, Kecamatan Bayan, KabupatenPurworejo". JurnalDipenogoro Law Jurnal.Vol. 6.No.2. 2017.

Nurhayati, Nunik. "Qua Vadis Perlindungan HakAsasi Manusia Dalam Penyelesaian Pelanggaran HAM Berat Masa Lalu Melalui Jalur Non Yudisial”.Jurnal Jurisprudence. Vol. 6.No. 2. September 2016.

Prakoso, Dian Eko. "Efektivitas Peraturan Daerah Nomor 17 Tahun 2006 Tentang Pengelolaan Parkir Tepi Jalan Umum Dalam Daerah Kota Makassar (Suatu Tinjauan Sosiologi Hukum)".Penelitian. Bagian Hukum Masyarakat Dan Pembangunan.Fakultas Hukum. Universitas Hasanuddin. Makassar, 2014.

Purwanti, Aryani Eka. "Efektivitas Undang-UndangNomor 19 Tahun 2002 Tentang Hak Cipta Dalam Memberantas Tindak Pidana Pembajakan VCD Di Surakarta".Penelitian.Fakultas Hukum. Universitas Maret Surakarta. Surakarta 2009.

Putra, Muhammad Amin. "Eksistensi Lembaga Negara Dalam Penegakan Hak Asasi Manusia Di Indonesia". Jurnal Ilmu Hukum. Vol. 9. No. 3. Juli-September 2015.

Rafes, JootjeJafet. "Penyelesaian Perkara Pelanggaran HakAsasiManusia (ham) berat prajurit tentara nasional Indonesia (tni).Vol. 1, No. 3, Juli-September 2013.

Rosana, Elly. "Kepatuhan Hukum Sebagai Wujud Kesadaran Hukum Masyarakat". Jurnal TAPIS. Vol. 10,.No. 1.Januari-Juni 2014.

Saptohadi, Satrio. "Eksistensi Pengadilan HakAsasi Manusia Dalam Penegakan Hukum Di Timor Timur Pasca Jajak Pendapat".JurnalDinamikaHukum. Vol. 13.No. 2. Mei 2013.

Setiawan,Imam. "Tinjauan Terhadap Hukum Acara Peradilan Dalam Praktek Peradilan HAM". Penelitian.Bagian HukumAcara.Fakultas Hukum, Universitas Hasanuddin. Makassar, 2013.

Somantri, Gumilar Rusliwa. "Memahami Metode Kualitatif". Sosial Humaniora.Vol. 9.No. 2.Desember 2005.

Supriyanto,BambangHeri. "Penegakan Hukum Mengenai HakAsasiManusia (HAM) Menurut HukumPositif di Indonesia". Jurnal Al-Azhar Indonesia Seri PranataSosial.Vol. 2.No. 3.Maret 2014. 